\begin{tabular}{|c|c|c|}
\hline \multirow{3}{*}{$\begin{array}{r}\text { Case Reports in } \\
\text { Gastroenterology }\end{array}$} & \multicolumn{2}{|c|}{ Case Rep Gastroenterol 2013;7:299-303 } \\
\hline & $\begin{array}{l}\text { DOI: 10.1159/000354140 } \\
\text { Published online: July } 18,2013\end{array}$ & $\begin{array}{l}\text { ( ) } 2013 \text { S. Karger AG, Basel } \\
1662-0631 / 13 / 0072-0299 \$ 38.00 / 0 \\
\text { www.karger.com/crg }\end{array}$ \\
\hline & $\begin{array}{l}\text { This is an Open Access article licel } \\
\text { NonCommercial-NoDerivs } 3.0 \\
\text { online version of the article only }\end{array}$ & $\begin{array}{l}\text { Is of the Creative Commons Attribution } \\
\text { er.com/OA-license), applicable to the } \\
\text { on-commercial purposes only. }\end{array}$ \\
\hline
\end{tabular}

\title{
Feasible Isolated Liver Transplantation for a Cirrhotic Patient on Chronic Hemodialysis
}

\author{
Kazutoyo Morita Ken Shirabe Tomoharu Yoshizumi Toru Ikegami \\ Toshiro Masuda Naotaka Hashimoto Yohei Mano Tatsunori Miyata \\ Yuji Soejima Yoshihiko Maehara \\ Department of Surgery and Science, Graduate School of Medical Sciences, Kyushu \\ University, Fukuoka, Japan
}

\section{Key Words}

Living donor liver transplantation $\cdot$ Hepatitis $C \cdot$ Hemodialysis

\begin{abstract}
End-stage liver and kidney disease (ELKD) is an indication for deceased donor simultaneous liver-kidney transplantation. Although a few cases of living donor liver-kidney transplantation have been reported, the invasiveness remains to be discussed. Living donor liver transplantation (LDLT) is an alternative choice for ELKD, but has never been reported. Here, we report a case of successful LDLT for a patient with ELKD on hemodialysis. The patient was a 63-yearold male and had decompensated hepatitis $C$ cirrhosis with seronegativity for hepatitis $C$ virus. He had non-diabetic end-stage renal failure and had been on hemodialysis for 3 years. He was in good general condition except for hepatic and renal failure. The living donor was his 58-year-old healthy wife. A right lobe graft was transplanted to the recipient under continuous hemodiafiltration (CHDF) and extracorporeal veno-venous bypass. CHDF was continued until postoperative day 4 , at which point CHDF was converted to hemodialysis. His posttransplant course was good and he was discharged on postoperative day 36 . To the best of our knowledge, this is the first report of LDLT for a patient on chronic hemodialysis. Therefore, being on hemodialysis is not a contraindication for LDLT. LDLT is feasible for a patient with ELKD on hemodialysis.

(c) 2013 S. Karger AG, Basel
\end{abstract}


Morita et al.: Feasible Isolated Liver Transplantation for a Cirrhotic Patient on Chronic Hemodialysis

\section{Introduction}

Peritransplant renal failure is an indicator of poor prognosis after liver transplantation [1-4]. End-stage liver and kidney disease (ELKD) on hemodialysis is an indication for deceased donor simultaneous liver-kidney transplantation (LKT) $[4,5]$. On the other hand, living donation of liver and a kidney is generally too challenging and invasive to be performed, and only a few cases of living donor simultaneous or sequential LKT for ELKD have been reported [6-10]. In living donor transplantation settings, the safer alternative approach is living donor liver transplantation (LDLT) and continuation of hemodialysis. However, LDLT for a patient on hemodialysis has never been reported, and thus the indications for LDLT in such patients are also unknown.

Here we present a case of successful LDLT for a patient with ELKD on hemodialysis. The indications for LDLT in patients on hemodialysis are presented and discussed.

\section{Case Report}

The recipient was a 63-year-old Japanese male who had been suffering from hepatitis $\mathrm{C}$ cirrhosis since the age of 37 years. He had undergone endoscopic variceal ligation for esophageal varices at the age of 58 years. His liver function had gradually become decompensated and he had developed hepatic encephalopathy 5 months before admission. He had had cryptogenic chronic nephritis from the age of 19 years and started hemodialysis at the age of 60 years. He had no other complications such as diabetes, hypertension or hemodialysis-related complications. His height was $159 \mathrm{~cm}$ and his weight was $53 \mathrm{~kg}$ before hemodialysis and $51 \mathrm{~kg}$ after hemodialysis. His Child-Pugh score was 10 (grade C) with a total bilirubin level of $0.9 \mathrm{mg} / \mathrm{dl}$, an albumin level of $3.4 \mathrm{~g} / \mathrm{dl}$ and a prothrombin time of $68 \%$ (international ratio 1.25). He was seropositive for hepatitis $\mathrm{C}$ virus (HCV) antibodies but seronegative for HCV RNA. The levels of blood urea nitrogen and creatinine were 61 and $9.01 \mathrm{mg} / \mathrm{dl}$, respectively. His model for end-stage liver disease score was 22. A computed tomography scan revealed the presence of liver cirrhosis, splenomegaly and developed collateral vessels such as splenorenal shunt, recanalized paraumbilical vein and gastric varices. No definite hepatocellular carcinomas were detected (fig. 1a). The bilateral kidneys were very atrophic, which was consistent with irreversible renal failure (fig. 1b). In summary, he had decompensated hepatitis C cirrhosis without serum HCV RNA. He had nondiabetic renal failure after 3 years on hemodialysis. He showed good general function except for the liver and kidney failure. Therefore, the patient was expected to have a good prognosis after LDLT.

The donor was his healthy 58-year-old wife with identical blood type to the recipient. The right lobe graft was procured using a typical method described elsewhere [1, 11-14]. The actual graft weight was $546 \mathrm{~g}$, which accounted for $50.4 \%$ of the recipient's standard liver volume.

In the recipient, intraoperative continuous hemodiafiltration (CHDF) without water removal was started immediately via the right femoral vein after laparotomy. The CHDF provided a stable acid-base and electrolyte balance. A total hepatectomy and implantation were performed under stable hemodynamics using an extracorporeal veno-venous bypass. The V5, right inferior hepatic vein and right hepatic vein of the right lobe graft were reconstructed to have a co-orifice using the left internal jugular vein and explanted portal vein grafts of the recipient at the backtable according to our usual method $[15,16]$. Operative time was $14 \mathrm{~h} 22 \mathrm{~min}$. The anhepatic, cold ischemic and warm ischemic times were 140, 169 
and $65 \mathrm{~min}$, respectively. The blood loss was $2,000 \mathrm{~g}$, for which 10 units of red cell concentrate, 10 units of fresh-frozen plasma and 30 units of platelet concentrate were transfused.

The postoperative courses of the recipient and the donor were uneventful. CHDF was continued until postoperative day 4, at which point CHDF was converted to hemodialysis. The amount of water removal was appropriately adjusted according to blood pressure, central venous pressure and body weight. The drained ascites was below $500 \mathrm{ml} /$ day and all abdominal drains were removed by postoperative day 6 except for the biliary stents (table 1). Other than the renal replacement therapy and dose modulation of renal excretory drugs such as acyclovir, the perioperative management of the recipient was typical, as previously described [1, 11-14]. Immunosuppression was induced with intravenous methylprednisolone and then switched to oral prednisolone, cyclosporin A and mycophenolate mofetil. He left the intensive care unit on postoperative day 5 and was discharged on postoperative day 36 with good hepatic function.

\section{Discussion}

To the best of our knowledge, this is the first report of LDLT for a patient on chronic hemodialysis. Deceased donor LKT is a standard therapy for ELKD [4, 5]. The posttransplant 2-year survival rates are $75.9 \%$ for deceased donor LKT and $70.8 \%$ for deceased donor isolated liver transplantation for ELKD on hemodialysis [5]. On the other hand, living donor LKT is invasive for the donor and is not established. An alternative strategy is LDLT and continuation of hemodialysis. However, LDLT for a patient on hemodialysis is potentially risky, and most surgeons hesitate to perform the procedure. In fact, LDLT for a patient on hemodialysis has never been reported, and thus the indications are unknown.

In the present case, there were three indications for LDLT. First, the patient was seronegative for HCV RNA. Undetectable serum HCV RNA before liver transplantation has been shown to decrease the rate of posttransplant disease recurrence [17, 18]. Nudo et al. [18] reported that patients with sustained viral response for interferon therapy, as determined by a sensitive assay (lower limit $<600 \mathrm{IU} / \mathrm{ml}$ ), had no virological recurrence, histological recurrence or graft failure. The present patient was determined to be seronegative for HCV RNA by an even more sensitive assay (lower limit $<15 \mathrm{IU} / \mathrm{ml}$ ). Therefore, he was expected to have a good prognosis without hepatitis $C$ recurrence after LDLT. Second, the etiology for the renal failure was non-diabetic. Non-diabetic patients on hemodialysis show much better survival rates than diabetic patients on hemodialysis [19]. Third, the patient had only been on hemodialysis for 3 years and had no other complications. He had good general functions including cardiac and pulmonary functions. Taking these three factors into consideration, LDLT was indicated for this patient.

Simultaneous or sequential LKT from the donor was not indicated for two reasons. First, liver-kidney donation from a single donor has not been established and is very invasive, especially for the relatively old donor in this case ( 58 years of age). Second, the recipient was expected to continue hemodialysis because he had only been on hemodialysis for 3 years.

The intraoperative and postoperative points were use of CHDF, care of in-out balance and drug dose modulation. CHDF was very useful as a peritransplant renal replacement therapy with stable hemodynamics. The other managements did not need to be specialized.

In conclusion, to the best of our knowledge, this is the first report of LDLT for a patient on chronic hemodialysis. Being on hemodialysis is no contraindication for LDLT. Isolated LDLT is a feasible option for a patient with ELKD on hemodialysis. 
Morita et al.: Feasible Isolated Liver Transplantation for a Cirrhotic Patient on Chronic Hemodialysis

\section{Disclosure Statement}

The authors have no conflict of interest.

\section{References}

1 Ikegami T, Shirabe K, Soejima Y, Taketomi A, Yoshizumi T, Uchiyama H, et al: The impact of renal replacement therapy before or after living donor liver transplantation. Clin Transplant 2012;26:143-148.

-2 Gonwa TA, Mai ML, Melton LB, Hays SR, Goldstein RM, Levy MF, et al: Renal replacement therapy and orthotopic liver transplantation: the role of continuous veno-venous hemodialysis. Transplantation 2001;71:1424-1428.

- 3 Nair S, Verma S, Thuluvath PJ: Pretransplant renal function predicts survival in patients undergoing orthotopic liver transplantation. Hepatology 2002;35:1179-1185.

4 Davis CL, Feng S, Sung R, Wong F, Goodrich NP, Melton LB, et al: Simultaneous liver-kidney transplantation: evaluation to decision making. Am J Transplant 2007;7:1702-1709.

-5 Eason JD, Gonwa TA, Davis CL, Sung RS, Gerber D, Bloom RD: Proceedings of Consensus Conference on Simultaneous Liver Kidney Transplantation (SLK). Am J Transplant 2008;8:2243-2251.

-6 Haberal M, Abbasoglu O, Büyükpamukçu M, Bilgin N, Telatar H, Simşek H, et al: Combined liver-kidney transplantation from a living-related donor. Transplant Proc 1993;25:2211-2213.

-7 Marujo WC, Barros MF, Cury RA, Pacheco-Silva A, Sette H Jr: Successful combined kidney-liver right lobe transplant from a living donor. Lancet 1999;353:641.

-8 Astarcioglu I, Karademir S, Gülay H, Bora S, Astarcioglu H, Kavukcu S, et al: Primary hyperoxaluria: simultaneous combined liver and kidney transplantation from a living related donor. Liver Transpl 2003;9:433-436.

-9 Nakamura M, Fuchinoue S, Nakajima I, Kitajima K, Tojimbara T, Takasaki K, et al: Three cases of sequential liver-kidney transplantation from living-related donors. Nephrol Dial Transplant 2001;16:166-168.

10 Sato S, Fuchinoue S, Kimikawa M, Tojimbara T, Nakajima I, Teraoka S, et al: Sequential liver-kidney transplantation from a living-related donor in primary hyperoxaluria type 1 (oxalosis). Transplant Proc 2003;35:373-374.

11 Soejima Y, Taketomi A, Yoshizumi T, Uchiyama H, Harada N, Ijichi H, et al: Feasibility of left lobe living donor liver transplantation between adults: an 8-year, single-center experience of 107 cases. Am J Transplant 2006;6:1004-1011.

12 Taketomi A, Kayashima H, Soejima Y, Yoshizumi T, Uchiyama H, Ikegami T, et al: Donor risk in adult-to-adult living donor liver transplantation: impact of left lobe graft. Transplantation 2009;87:445-450.

-13 Shirabe K, Yoshimatsu M, Motomura T, Takeishi K, Toshima T, Muto J, et al: Beneficial effects of supplementation with branched-chain amino acids on postoperative bacteremia in living donor liver transplant recipients. Liver Transpl 2011;17:1073-1080.

14 Yoshizumi T, Shirabe K, Taketomi A, Uchiyama H, Harada N, Ijichi H, et al: Risk factors that increase mortality after living donor liver transplantation. Transplantation 2012;93:93-98.

15 Soejima Y, Ueda N, Fukuhara T, Yoshizumi T, Ikegami T, Yamashita Y, et al: One-step venous reconstruction for a right lobe graft with multiple venous orifices in living donor liver transplantation. Liver Transpl 2008;14:706-708.

16 Ikegami T, Soejima Y, Taketomi A, Yoshizumi T, Harada N, Uchiyama H, et al: Explanted portal vein grafts for middle hepatic vein tributaries in living-donor liver transplantation. Transplantation 2007;84:836-841.

17 Everson GT, Trotter J, Forman L, Kugelmas M, Halprin A, Fey B, et al: Treatment of advanced hepatitis C with a low accelerating dosage regimen of antiviral therapy. Hepatology 2005;42:255-262.

18 Nudo CG, Cortes RA, Weppler D, Schiff ER, Tzakis AG, Regev A: Effect of pretransplant hepatitis C virus RNA status on posttransplant outcome. Transplant Proc 2008;40:1449-1455.

19 Hocher B, Ziebig R, Altermann C, Krause R, Asmus G, Richter CM, et al: Different impact of biomarkers as mortality predictors among diabetic and nondiabetic patients undergoing hemodialysis. J Am Soc Nephrol 2003;14:2329-2337. 


\section{Case Reports in
Gastroenterology}

\begin{tabular}{l|l}
\hline Case Rep Gastroenterol 2013;7:299-303 \\
\hline DOI: 10.1159/000354140 & $\begin{array}{l}\text { @ 2013 S. Karger AG, Basel } \\
\text { www.karger.com/crg }\end{array}$ \\
\hline
\end{tabular}

Morita et al.: Feasible Isolated Liver Transplantation for a Cirrhotic Patient on Chronic Hemodialysis

Table 1. Posttransplant course

\begin{tabular}{llll}
\hline POD & $\begin{array}{l}\text { Renal replacement/ } \\
\text { water removal, } \mathrm{ml}\end{array}$ & $\begin{array}{l}\text { Ascites, } \\
\mathrm{ml}\end{array}$ & $\begin{array}{l}\text { Body weight, } \\
\mathrm{kg}\end{array}$ \\
\hline 1 & CHDF $/ 420$ & 385 & 54.1 \\
2 & CHDF $/ 1,290$ & 122 & 54.5 \\
3 & CHDF $/ 1,010$ & 278 & 54.1 \\
4 & HD $/ 2,000$ & 191 & 53.1 \\
5 & none & 65 & 52.5 \\
6 & none & none & 53.6 \\
7 & HD $/ 1,800$ & none & 52.8 \\
\hline
\end{tabular}

POD = Postoperative day; HD = hemodialysis.
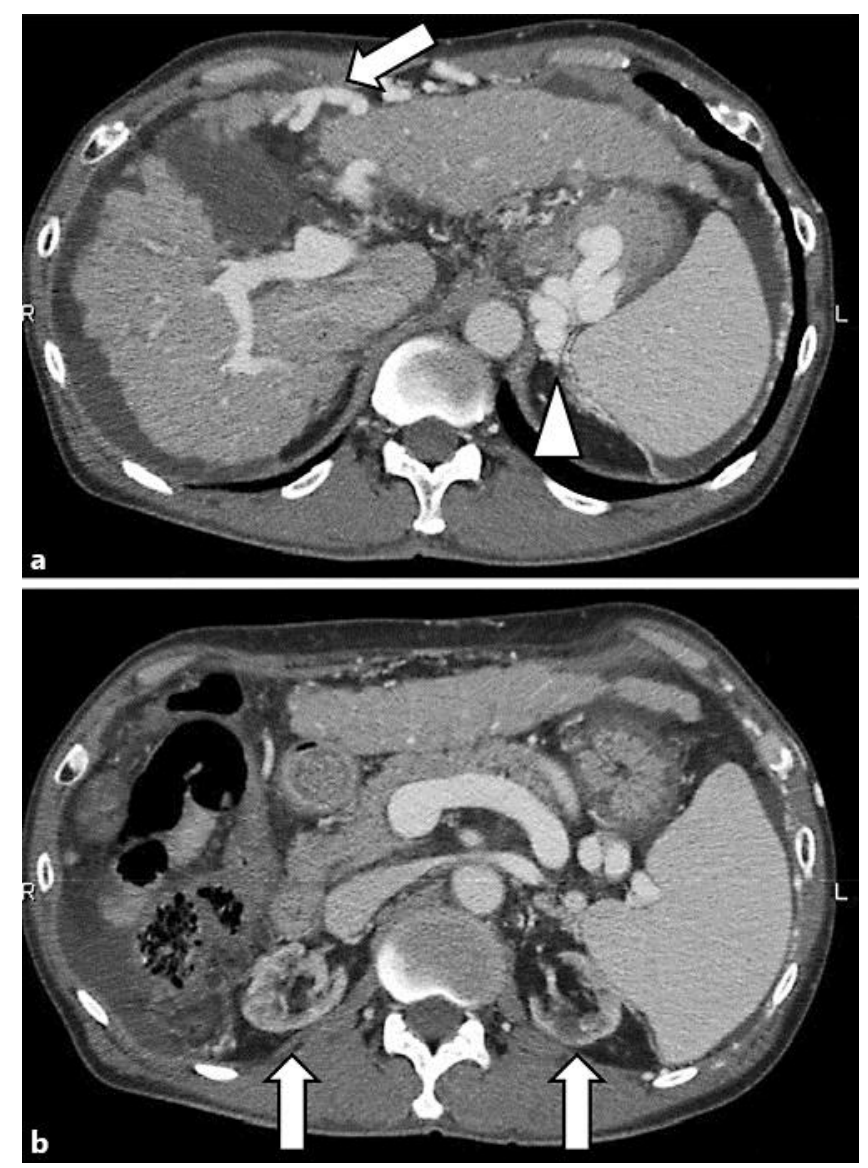

Fig. 1. Pretransplant computed tomography scan. a The liver was cirrhotic and had no definite hepatocellular carcinomas. Moderate ascites, recanalized paraumbilical vein (arrow), gastric varices (arrowhead) and splenomegaly were identified. b The bilateral kidneys were very atrophic (arrows). 